\title{
Plant Science
}

\section{REGULAR ARTICLE}

\section{Isolation of thermotolerant and high acetic acid-producing Acetobacter pasteurianus from Ivorian palm wine}

\author{
Moussa Konate ${ }^{1 *}$, Eric Essoh Akpa ${ }^{1}$, Louis Ban Koffi ${ }^{2}$, Kouassi Aboutou Sévérin Kra ${ }^{1}$, Rose-Monde Megnanou ${ }^{1}$ \\ and Sébastien Niamke ${ }^{1}$ \\ ${ }^{1}$ Laboratoire de Biotechnologies, Filière Biochimie-Microbiologie; Unité de Formation et de Recherche en Biosciences. \\ Université Félix Houphouët Boigny, Cocody-Abidjan 22 BP 582 Abidjan 22 Côte d'Ivoire \\ ${ }^{2}$ Laboratoire de Microbiologie, Centre National de Recherche Agronomique (CNRA), Abidjan Km17 Route de Dabou: \\ 01 BP 1740 Abidjan 01 Côte d'Ivoire
}

\begin{abstract}
The aim of this work was to identify acetic acid bacteria expressing technological characteristics for further use in vinegar production in tropical countries. It was focused on isolation and identification of thermotolerant acetic acid bacteria strains from Elaeis guineensis wine of Côte d'Ivoire (Ivorian palm wine). A screening was performed to find out strains with high vinegar production, tolerant against high ethanol, acid and sugar concentrations as well as tolerating high production temperatures. Among 104 isolated strains, 5 were selected for their growth ability, acetification capacity (acetic acid production higher than $30 \mathrm{~g} / \mathrm{l}$ ) and suroxydation at $37^{\circ} \mathrm{C}$. Tolerance against $6 \%$ acetic acid and $9 \%$ ethanol was observed. Osmotolerance study showed tolerance against $5 \%$ and $10 \%$ glucose giving $100 \%$ and $50 \%$ relative growth, respectively. Resistance against desiccation showed survival rate of $50 \%$ at $37^{\circ} \mathrm{C}$ after $5 \mathrm{~h}$ treatment and $10 \%$ after $20 \mathrm{~h}$ treatment. The best aeration rate in flasks for acetification was $70 \%$. Polyphasic identification study based on biochemical, physiological and molecular characterization showed that the 5 isolates were all Acetobacter pasteurianus. Owing to their potentialities, these strains may be used as starters in vinegar production after conducting preservation studies.
\end{abstract}

Key words: Acetic acid bacteria, Acetic fermentation, Acetobacter pasteurianus, Gram staining

\section{Introduction}

Acetic acid bacteria (AAB) are a large group of obligate aerobic gram negative bacteria with the ability to oxidize ethanol to acetic acid (Matsushita et al., 1994). They are widely distributed in natural habitats and classified in the family of Acetobacteriaceae. Members of this family are useful in industrial production of vinegar (Adachi et al., 2003). AAB can use substrates such as glucose, ethanol, lactate or glycerol as energy sources. However, most of these compounds are not completely oxidized into $\mathrm{CO}_{2}$ and $\mathrm{H}_{2} \mathrm{O}$ but several metabolites, especially acetic acid, are accumulated

Received 07 April 2014; Revised 30 May 2014; Accepted 31

May 2014; Published Online 01 July 2014

*Corresponding Author

Moussa Konate

Laboratoire de Biotechnologies, Filière BiochimieMicrobiologie; Unité de Formation et de Recherche en Biosciences. Université Félix Houphouët Boigny, CocodyAbidjan 22 BP 582 Abidjan 22 Côte d'Ivoire

Email:moukontys@gmail.com in the growth medium. $\mathrm{AAB}$ are commonly found in nature because of their high resistance to acidity and the variety of substrates that they can use (De Ley et al., 1984). These bacteria can be isolated from vinegar, fruits, flowers, bees honey, sugar cane juices, soil, water and alcoholic beverages (Yamada et al., 1999). Vinegar can be produced from several sources such as grapes, apples, beetroots, potatoes, honey and some many other tropical fruits like pineapples, dates, oranges, grapefruits, pawpaws and bananas (Ould el Hadj et al., 2001).

Vinegar production through biotechnological means has acquired considerable interest due to the possible use of acetic acid bacteria to produce acetic acid. The recommendations of European Union Norm 2-3-1 AFNOR / CEN (NF EN 13188, 2000) had even allowed the use of foods arising from natural materials processing. In addition, secondary metabolites produced into biotechnological vinegar can increase its final quality. According to Beheshti and Shafiee (2009), around 50 types of volatile and aromatic 
compounds are produced when vinegar is obtained by biotechnological methods.

In African sub-Saharan countries temperatures are generally above $30^{\circ} \mathrm{C}$ while common $\mathrm{AAB}$ are mesophilic microorganisms and their optimum growth temperature is between $25^{\circ} \mathrm{C}$ and $30^{\circ} \mathrm{C}$ (Gullo et al., 2008). In such conditions, the production of vinegar with $\mathrm{AAB}$ can be disadvantageous for factories because of the cooling expenses of bioreactors (Adachi et al., 2003). There by vinegar producing technology using thermotolerant strains that are able to grow and produce acetic acid at higher temperatures would be advantageous in these tropical countries (Ndoye et al., 2006). Therefore, there is a real need to find out strains that are tolerant to uttermost growth conditions (temperature, desiccation, alcohol and acid), and also capable to produce high level of acetic acid (Lu et al., 2000).

Thermotolerance, and tolerance against alcohol and acetic acid were previously studied (Ndoye et al., 2006; Amornrut et al., 2008; Kanlaya et al., 2009). Illeghems et al. (2013) have isolated an acetic acid bacterium (Acetobacter pasteurianus 386B) originating from a spontaneous cocoa bean heap fermentation that proved to be an ideal functional starter. It was able to dominate the fermentation process, thereby resisting high acetic acid concentrations and temperatures. Generally, strains were able to grow at temperatures up to 37$40^{\circ} \mathrm{C}$. Alcohol tolerance was found until $10 \%(\mathrm{v} / \mathrm{v})$ and acetic acid tolerance was more than $4 \%(\mathrm{v} / \mathrm{v})$. Those authors checking thermotolerant acetic acid bacteria mentioned that using these strains can be economic by reducing cooling water expenses of bioreactors until $30^{\circ} \mathrm{C}$ (optimum growth temperature of common acetic acid bacteria).

The potential sources of bacteria strains tolerant to such drastic conditions are found in tropical fruits and beverages such Elaeis guineensis wine of Côte d'Ivoire (Ivorian palm wine), a popular local alcoholic beverage. This beverage is known to naturally and frequently contain acetic acid bacteria (Okafor, 1975). In this study, AAB strains were first isolated from Ivorian palm wine and then a screening was performed to select strains with high potentialities for vinegar production. The selected strains were subjected to polyphasic characterization.

\section{Materials and Methods \\ Isolation and screening}

The biological material used was a three days old palm wine that was expected to contain acetic acid strains (Okafor, 1975). Owing to the acidity increasing of the beverage a personal communication allowed us to obtain palm wine for analyses. The juice obtained from cut down palm trees was conserved until it becomes wine within three days. The strains isolations were performed following Duthathai and Wasu (2007) method which was modified by adding Nystatine to the medium after sterilization. This medium was GYC (Glucose Yeast Carbonate) (Duthathai and Wasu, 2007), pH 6, containing $0.5 \%$ glucose, $2 \%$ glycerol, $1 \%$ yeast extracts, $1 \%$ peptone, $1.5 \%$ potatoe extract, $1 \% \quad \mathrm{CaCO}_{3}, \quad 4 \%$ ethanol, $0.0016 \%$ bromocresol green and 1.5\% agar. Dilutions from the sample (the 3 days old palm wine) were prepared in peptone water and $100 \mu$ of various dilutions were then spread in Petri dishes and incubated at $30^{\circ} \mathrm{C}$ for 3-4 days under aerobic conditions. Isolated colonies with yellow zones around were streaked on Hestrin-Schramm $\mathrm{CaCO}_{3}$ Agar medium to confirm acid production by formation of clear zones around colonies (Andelib and Nuran, 2009). This medium was composed of $0.05 \%$ glucose, $0.3 \%$ peptone, $0.5 \%$ Yeast extract, $1.5 \% \mathrm{CaCO}_{3}, 1.2 \%$ agar, and $1.5 \%$ ethanol was had after sterilization. Culture was performed at $30^{\circ} \mathrm{C}$ for 2-7 days. Confirmed acid forming colonies with the biggest clear zones were subjected to further biochemical tests.

They were allowed to a secondary screening in liquid medium. Modified Hestrin-Schramm (HS) $\mathrm{CaCO}_{3}$ broth composed of $2.5 \%$ ethanol, $0.5 \%$ Yeast extract, $0.5 \%$ peptone, $0.27 \% \mathrm{Na}_{2} \mathrm{HPO}_{4}$ and $0.01 \% \mathrm{MgSO}_{4}$ was used as basal medium for that purpose (Andelib \& Nuran, 2009). $\mathrm{YGM} / \mathrm{Mg}^{2+}$ medium (Yeast Glucose Mannitol with $\mathrm{MgSO}_{4}$ ) (Ndoye et al., 2006) containing yeast extract 1\%, glucose $2 \%$, mannitol $2 \%, \mathrm{MgSO}_{4} 0.01 \%$, ethanol $2.5 \%$ and acetic acid $0.5 \%$ (Ndoye et al., 2006) was used for seed culture until optic density at $600 \mathrm{~nm}$ $\left(\mathrm{OD}_{600}\right)$ of 0.5 was achieved. Culture experiments were performed in 250 ml-Erlenmeyer flasks containing $150 \mathrm{ml}$ of basal medium. The media were inoculated with $1 \mathrm{ml}$ of seed culture. Cultures were carried out in a shaking bath at $30^{\circ} \mathrm{C}, 35^{\circ} \mathrm{C}$, $37^{\circ} \mathrm{C}, 39^{\circ} \mathrm{C}$ and $40^{\circ} \mathrm{C}$.

Bacterial growth was followed within 10 days and evaluated at $\mathrm{OD}_{600}$. Acetic acid production was measured by titration with $\mathrm{NaOH} 0.5 \mathrm{~N}$ with phenolphthalein as $\mathrm{pH}$ indicator. This titration was performed as follow: $10 \mathrm{ml}$ of the broth medium were mixed thoroughly with 3-5 drops of phenolphthalein [phenolphthalein, $0.1 \mathrm{~g}$; ethanol, $60 \mathrm{ml}$; distilled water, $40 \mathrm{ml}$ ] and then $0.5 \mathrm{~N}$ sodium hydroxide $(\mathrm{NaOH}, 20 \mathrm{~g}$; distilled water, $1000 \mathrm{ml}$ ) were added until appearance of pale pink 
color in the flask. The amount $(\mathrm{g})$ of acetic acid (Aaa) produced in $1000 \mathrm{ml}(1 \mathrm{l})$ of medium was calculated using the following formula:

Aaa $(g / l)=N_{\mathrm{NaOH}} \times \mathrm{V}_{\mathrm{NaOH}} \times 1000 \times \mathrm{M}_{\text {acetic acid }} /$ $\mathrm{V}_{\text {assay, }}$, where:

Aaa: acetic acid yield (g/l)

$\mathrm{N}_{\mathrm{NaOH}}$ : $\mathrm{NaOH}$ normality $(0.5 \mathrm{~N})$

$\mathrm{V}_{\mathrm{NaOH}}: \mathrm{NaOH}$ volume used for titration

$\mathrm{M}_{\text {acetic acid: }}$ molar mass of acetic acid $(60 \mathrm{~g} / \mathrm{mol})$

$\mathrm{V}_{\text {assay: }}$ : volume of the assay $(\mathrm{ml})$

Multiplied by 1000 to obtain acetic acid yield in $\mathrm{g} / \mathrm{l}$

\section{Phenotypical and biochemical characterization}

Selected strains were submitted to characterization. Gram staining was performed and cells motility was observed by hanging drop method (Webley, 1953). Catalase test was performed with hydrogen peroxide and oxidase test with oxidase disks.

Overoxidation was investigated with HS broth containing bromocresol green. It was based on the capacity of strains to oxidate acetate to $\mathrm{CO}_{2}$ and $\mathrm{H}_{2} \mathrm{O}$ giving yellow color to the medium that turns finally into green (Holt et al., 1994).

Biochemical studies were performed by checking acid production in modified HestrinSchramm (HS) broth containing 1\% sugar as the only source of carbon (Andelib and Nuran, 2009) and $0.0016 \%$ bromocresol green. The following sugars were used: galactose, glucose, mannitol, acetic acid, lactic acid, glycerol, sucrose, mannose, sorbitol, ethanol, fructose, and xylose. One $\mathrm{ml}$ of each strain suspension $\left(\mathrm{OD}_{600}=0.5\right)$ was used to inoculate tubes containing $10 \mathrm{ml}$ of each sugar. Acid production is indicated by changing color of the initial blue-green media into yellowish one.

Bacterial tolerance against acetic acid and alcohol were analyzed in HS broth containing respectively acetic acid $1-10 \%$ and alcohol $1-15 \%$ as sole carbon sources in the media. Ten (10) $\mathrm{ml}$ of each acid or alcohol solution were inoculated with $1 \mathrm{ml}$ of a $0.5 \mathrm{OD}_{600}$ seed culture. Cells viability was estimated after incubation at $37^{\circ} \mathrm{C}$ for $48 \mathrm{~h}$ by counting colonies with and without treatment. Strains were considered tolerant to the treatment if $\triangle \log \mathrm{N}_{10}\left(\log \mathrm{N}_{0}-\log \mathrm{N}_{1}\right) \leq 5$ (Legrand-Sow, 2004) where, $\Delta \log N_{10}=$ Decimal Logarithm variation, $\mathrm{N}_{0}=$ Number of viable cells before treatment, $\mathrm{N}_{1}=$ number of viable cells after treatment.

The influence of aeration on acetic acid production was also studied in flasks. For that purpose, volumes of aeration (ratio of medium volume / flask volume) ranging from 10 to $90 \%$ were prepared with HS broth. Culture media were inoculated with $0.5 \mathrm{OD}_{600}$ seed cultures using $1 \mathrm{ml}$ for every $150 \mathrm{ml}$ of broth. Incubation was achieved in a shaking bath at $130 \mathrm{rpm}$ at $37^{\circ} \mathrm{C}$ within 7 days. Acetic acid production in each flask was determined by titration with $\mathrm{NaOH} 0.5 \mathrm{~N}$ using phenolphthalein as indicator.

Osmotolerance of strains was studied with glucose concentrations ranging from 2 to $30 \%$ in modified HS medium and measurement of absorbance at $600 \mathrm{~nm}$. Incubation in a shaking bath at $130 \mathrm{rpm}$ at $37^{\circ} \mathrm{C}$ within 7 days was observed. Cells relative growth (RG) was calculated with considering as $100 \% \mathrm{RG}$, the highest $\mathrm{OD}_{600}$ observed (Jojima et al., 2004).

Resistance test against desiccation was carried out by preparing suspensions from selected strains, into $\mathrm{YGM} / \mathrm{Mg}^{2+}$ medium at $30^{\circ} \mathrm{C}$ with $130 \mathrm{rpm}$ shaking. At $0.5 \mathrm{OD}_{600}$, each suspension was centrifuged at $9600 \mathrm{~g}$ for $10 \mathrm{~min}$ at $4^{\circ} \mathrm{C}$. After washing twice with potassium phosphate buffer (KPB) $50 \mathrm{mM} \mathrm{(pH} \mathrm{5.5-6),} \mathrm{cell} \mathrm{pellets} \mathrm{were}$ resuspended in the same buffer. One milliliter of that solution was submitted to cell counting while one other milliliter was filtered onto sterile polycarbonate membranes $(0.45 \mu \mathrm{m})$. Thereafter, the filters were exposed to drying at $37^{\circ} \mathrm{C}$ during 72 $\mathrm{h}$ in half-opened Petri dishes. At time intervals, filters containing dried cells were put into $10 \mathrm{ml}$ of peptone water and incubated for $10 \mathrm{~min}$ at $30^{\circ} \mathrm{C}$ on YGM/ $\mathrm{Mg}^{2+}$ medium (Laura et al., 2001, modified). Viable cells were then submitted to plate counting in triplicate. The ratio of viable cells in the rehydrate to initial culture gives the desiccation effect ton strains (Lewis et al., 2010). According to modifications sterile polycarbonate membranes $(0.45 \mu \mathrm{m})$ were used instead of pieces of sterile gauze $\left(1 \mathrm{~cm}^{2}\right)$ that were imbibed separately with 1 $\mathrm{ml}$ of a $48-\mathrm{h}$ culture $\left(10^{6} \mathrm{cfu} / \mathrm{ml}\right)$ of each strain in tryptose broth. YGM/ $\mathrm{Mg}^{2+}$ medium were also used instead of blood agar medium. In addition, inoculums were washed and centrifuged before using.

\section{Molecular characterization}

The genomic DNA preparation was performed by the heat shock methods. Bacteria were grown in $\mathrm{YGM} / \mathrm{Mg}^{2+}$ agar medium for $24 \mathrm{~h}$ at $30^{\circ} \mathrm{C}$. Cell suspensions were made using some colonies in 400 $\mu l$ of milli-Q water into Eppendorf tubes. The tubes were then frozen at $-20^{\circ} \mathrm{C}$ for $20 \mathrm{~min}$ before heating them in a heat block at $100^{\circ} \mathrm{C}$ for $20 \mathrm{~min}$. Afterwards, tubes were centrifuged at $+4^{\circ} \mathrm{C}$ for 10 min at $14000 \mathrm{rpm}$. The supernatants containing total genomic DNA were poured in new sterile 
tubes and conserved at $+4^{\circ} \mathrm{C}$ or $-20^{\circ} \mathrm{C}$ if not used immediately.

The following Polymerase Chain Reaction (PCR) amplification was based on the analysis of the $16 \mathrm{~S}$ rDNA. It was monitored with an universal primer consisting of a forward primer 16F27: 5'AGAGTTTGATCCTGGCTCAG-3' and a reverse primer 16R1522: 5'AAGGAGGTGATCCAGCCGCA-3', localized respectively on positions 8-27 and 1541-1522 according to the nomenclature system in force with Escherichia coli (Brosius et al., 1978). The PCR kit, Hot Master Mix 5 PRIME (Dominique Deutcher, France) was used. It was composed of 20 $\mu 1$ of Mix, $0.2 \mu \mathrm{l}$ of each primer, $1 \mu 1 \mathrm{ADN}$ (50 ng) and supplemented by sterile milli-Q water to achieve a final volume of $50 \mu \mathrm{l}$. PCR amplification was carried out in a thermocycler (Mastercycler Personal, Eppendorf, Pecq, France) with the following procedure: a first denaturation step of the DNA at $95^{\circ} \mathrm{C}$ for $2 \mathrm{~min}$, then denaturation at $95^{\circ} \mathrm{C}$ for $1 \mathrm{~min}$, primers annealing at $58^{\circ} \mathrm{C}$ for $30 \mathrm{sec}$, primers extension at $65^{\circ} \mathrm{C}$ for $2 \mathrm{~min}$ and a final extension cycle at $65^{\circ} \mathrm{C}$ for $7 \mathrm{~min}$. A total of 35 cycles were done.

Isolates were then identified by sequencing the PCR products in a sequencer ABI 3730xl 96capillary DNA Analyzers (Eurofins genomics, Paris, FRANCE). Genomic DNA of strains and their PCR products were sent to Eurofins genomics, Paris, FRANCE for sequencing and the sequencer ABI 3730xl 96-capillary DNA Analyzers was used. The analyses were performed by Eurofins platform by SANGER methods.

Sequences analyses were performed with National Center for Biotechnology Information (NCBI) software using nucleotide Basic Local Alignment Search Tool (BLAST) method (http://www.blast.ncbi.nlm.nih.gov). BLAST finds regions of local similarity between sequences. The program compares nucleotide or protein sequences to sequence databases and calculates the statistical significance of matches. BLAST can be used to infer functional and evolutionary relationships between sequences as well as help identify members of gene families.

\section{Analysis of samples}

Experiments were performed in triplicate for samples where standard deviations were calculated and in duplicate for those presented as the mean standard values of two replicates. All these analysis were done with Microsoft Office Excel 2007.

\section{Results and Discussion}

We aimed in this study to look for bacterial strains capable of growing well at high temperatures and producing high level of acetic acid. Physiological, biochemical and molecular studies were performed to characterize selected strains.

Acetic acid bacteria were obtained from palm wine. First day palm wine was sweet. No acetic acid bacteria were detected in it (personal communication). Third day palm wine were sour meaning the presence of microorganisms responsible for this transformation. This three days palm wine ( $\mathrm{pH} 3.4$ - 4.1) was used to obtain a total of 104 acetic acid strains.

All isolates showed yellow zone on GYC medium (Figure 1 a) and clear zones on HS $\mathrm{CaCO} 3$-Agar plates (Figure $1 \mathrm{~b}$ ). They were all Gram-negative (Figure $1 \mathrm{c}$ ) and motile by means of peritrichous flagella, and the colonies were circular and non-pigmented. They were all fermenting alcohol into acetic acid (Figure $1 \mathrm{~d}$ ), negative for oxidase, and positive for catalase. Oxidation of acetate to $\mathrm{CO}_{2}$ and $\mathrm{H}_{2} \mathrm{O}$ was found positive in all strains and this ability to oxidize acetate was used to confirm their membership to the genus Acetobacter spp.

From primary screening based on diameter's length of clear zones, twenty (20) strains with diameter up to $1.2 \mathrm{~cm}$ were selected. They were then allowed for a secondary screening with checking good bacterial growth and high acetic acid production at increasing temperature. As results, 20 strains grew and produced acid at $30^{\circ} \mathrm{C}, 16$ among the 20 strains grew and produced acid at $35^{\circ} \mathrm{C}, 13$ among the 16 strains grew and produced acid at $37^{\circ} \mathrm{C}$ and only 2 among the 13 strains grew and produced acid at $39^{\circ} \mathrm{C}$. Neither growth nor acid production was observed beyond $39^{\circ} \mathrm{C}$. At least, five (5) strains were selected. They were composed of the two acid producing strains at $39^{\circ} \mathrm{C}$ ( UFHBLBAAB003 (S3) and UFHB-LBAAB032 (S32)) and three other strains that were among the highest acid producers at $37^{\circ} \mathrm{C}$ (UFHB-LBAAB004 (S4), UFHB-LBAAB011 (S11) and UFHB-LBAAB013 (S13)). All five strains showed good growth and acid production up to $30 \mathrm{~g} / \mathrm{L}$ at $37^{\circ} \mathrm{C}$ (optimum temperature). The following results concern all the studies allowed to characterize these five strains. 


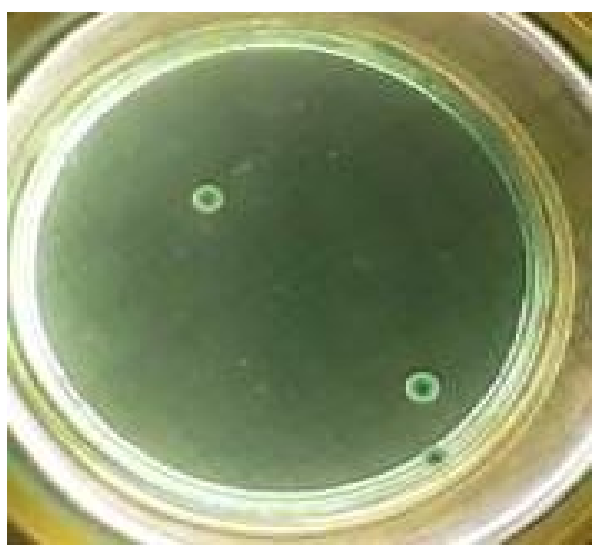

(a)

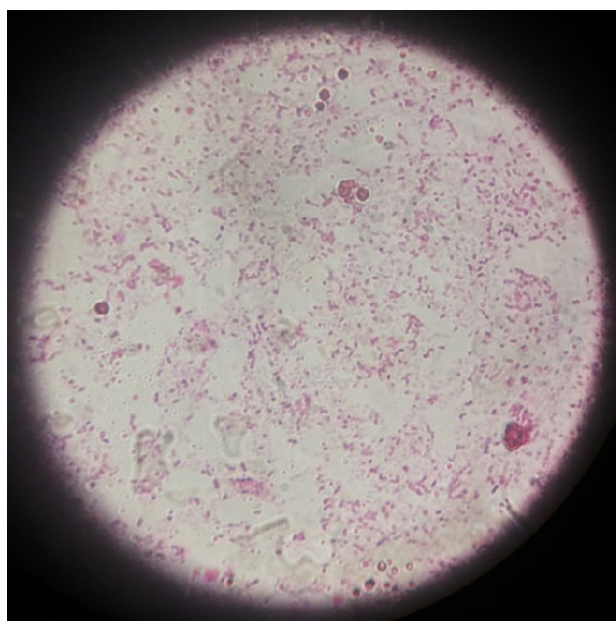

(c)

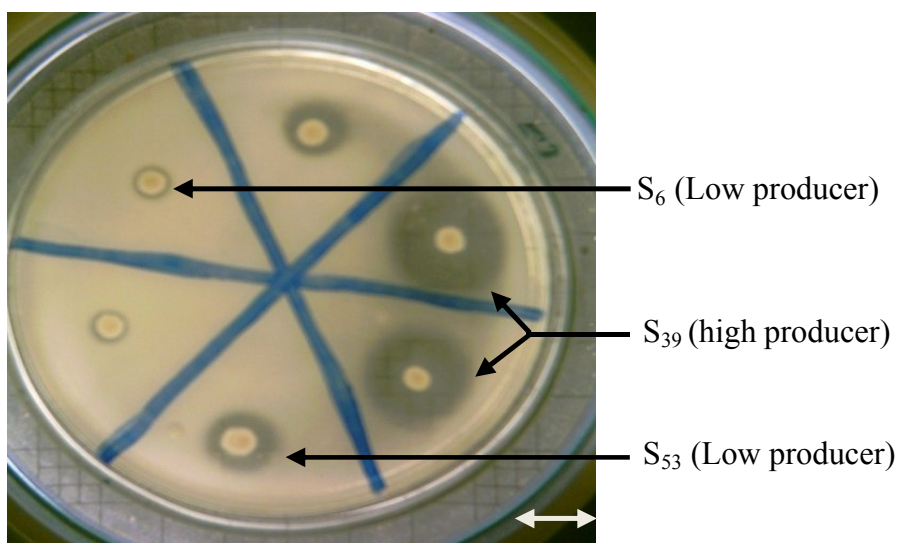

(b)

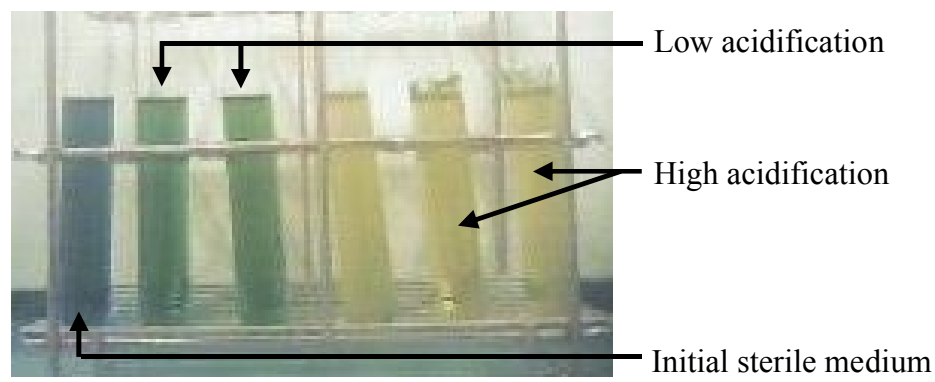

(d)

Figure 1. Acetic acid bacteria isolation from Ivorian palm (Elaeis guineensis) wine and acetification checking. (a) Isolation of acetic acid bacteria using GYC medium. Incubation was performed at $30^{\circ} \mathrm{C}$ within five days. Colonies showing yellow zone around were purified for further studies. (b) : Screening of purified acetic acid bacteria isolated on GYC medium, based on acetic acid production. Purified strains were repiquated onto modified Hestrin-Schramm (HS) $\mathrm{CaCO}_{3}$ medium within $4-5$ days at $30^{\circ} \mathrm{C}$. Strains giving biggest clear zone sizes were considered as high producers. (c): Gram staining (gram negative) of an isolated Acetobacter pasteurianus strain. Culture was obtained after 24 hours incubation at $30^{\circ} \mathrm{C}$ in YGC culture media. (d) : Acetification checking with Acetobacter pasteurianus strains. Modified Hestrin-Schramm (HS) broth with ethanol as the only carbon source was used. Cultures were incubated at $30^{\circ} \mathrm{C}$ within 72 hours. Two strains showed low acetification and the three other strains showed high acetification.

Other biochemical and confirmatory tests of selected strains were shown in Table 1. The isolates were able to oxidize xylose, glycerol, glucose, ethanol, acetic acid, lactic acid and unable to oxidize Galactose, mannose, sucrose, mannitol, sorbitol and fructose. From then on, they seemed to be Acetobacter or Gluconacetobacter by referring on previous work made by Urakami et al. (1989) and Lisdiyanti et al. (2002).

Following PCR amplification (Figure 2) and analysis of the 16SrDNA of the studied strains allowed their accurate identification. The 16SrDNA sequences showed high levels of similarity of the five strains to Acetobacter pasteurianus. We obtained $98 \%$ of similarity for UFHB-LBAAB004 (S4) and UFHB-LBAAB011 (S11) and 99\% for UFHB-LBAAB003 (S3), UFHB-LBAAB013 (S13) and UFHB-LBAAB032 (S32). 
Table 1. Biochemical analysis of the 5 selected Acetobacter strains isolated from Ivorian palm wine.

\begin{tabular}{llllll}
\hline \multirow{2}{*}{$\begin{array}{l}\text { Carbon } \\
\text { sources }\end{array}$} & \multicolumn{5}{l}{ Isolates } \\
\cline { 2 - 6 } & S3 & S4 & S11 & S13 & S32 \\
\hline Galactose & - & - & - & - & - \\
Xylose & + & - & - & - & + \\
Mannose & - & - & - & - & - \\
Glycerol & + & + & + & + & + \\
Sucrose & - & - & - & - & - \\
Mannitol & - & - & - & - & - \\
Glucose & + & + & + & + & + \\
Sorbitol & - & - & - & - & - \\
Ethanol & + & + & + & + & + \\
Fructose & - & - & - & - & - \\
Acetic & + & + & + & + & + \\
acid & & \multicolumn{5}{c}{} \\
Lactic acid & + & + & + & + & + \\
\hline Incubation was performed at 30 ${ }^{\circ}$ C for 48 h with 130 rpm \\
shaking in a Modified HS culture medium. S3: strain \\
UFHB-LBAAB003, S4: strain UFHB-LBAAB004, S11: \\
strain UFHB-LBAAB011, S13: strain UFHB- \\
LBAAB013, S32: strain UFHB-LBAAB032. (-) no \\
growth; (+) good growth and acidification
\end{tabular}

The bacterial growth (Figure 3) presented three phases characteristic of diauxic growth. A first growth phase during the first five days of incubation at $30^{\circ} \mathrm{C}$ (with $0.34-0.52 \mathrm{OD}_{600}$ ) and during the first three days at $35^{\circ} \mathrm{C}, 37^{\circ} \mathrm{C}$ and $39^{\circ} \mathrm{C}$ (with respectively $0.13-0.33,0.14-0.29$ and 0.10 $0.15 \mathrm{OD}_{600}$ for cultures at $35^{\circ} \mathrm{C}, 37^{\circ} \mathrm{C}$ and $39^{\circ} \mathrm{C}$ ). Then, a lag phase followed during two days. Thereafter, a second growth phase occurred with $0.52-1.09 \mathrm{OD}_{600}$ at $30^{\circ} \mathrm{C}$ and respectively $0.54-0.89$, $0.60-1.18,0.65 \mathrm{OD}_{600}$ for cultures at $35^{\circ} \mathrm{C}, 37^{\circ} \mathrm{C}$ and $39^{\circ} \mathrm{C}$.

The diauxic curves observed can be explained by total consumption of the first carbon source (alcohol) and the utilization of acetic acid obtained by alcohol oxidation as a second carbon source. Chinnawirotpisan et al. (2003) and Saeki et al. (1997, 1999) justified this biochemical phenomenon as follow: Acetobacter strains always show three growth characteristics in alcohol media. The first one is the alcohol oxidation into acetic acid, the second is a no growth step and the last one is the overoxidation of accumulated acetic acid.

In Figure 4 shows that the highest acetic acid productions were obtained between the seventh and the ninth day of incubation at $30^{\circ} \mathrm{C}$ and between the fifth and the seventh day of culture at $35^{\circ} \mathrm{C}, 37^{\circ} \mathrm{C}$ and $39^{\circ} \mathrm{C}$. These concentrations were respectively $15,0-26.1,20.4-27.6,31.5-33.9$ and $11.4-12.3 \mathrm{~g} / \mathrm{l}$ at $30^{\circ} \mathrm{C}, 35^{\circ} \mathrm{C}, 37^{\circ} \mathrm{C}$ and $39^{\circ} \mathrm{C}$. It can be noticed that

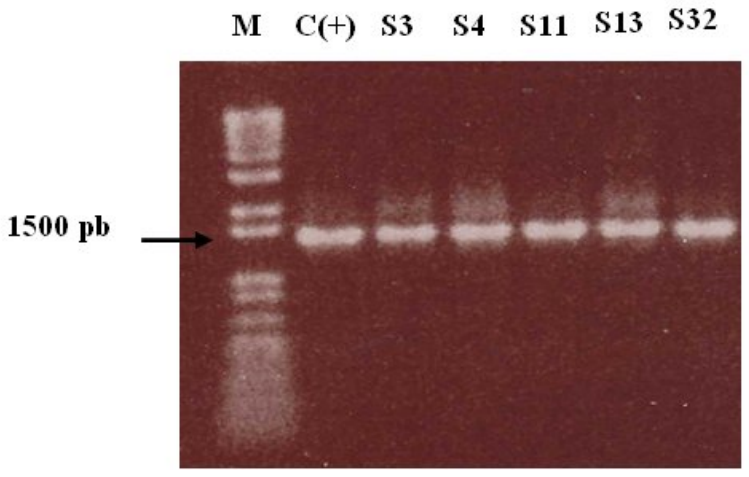

Figure 2. Agarose gel electrophoresis of five strains of acetic acid bacteria. $\mathrm{M}$ was Mark, $\mathrm{C}(+)$ was positif control (Lactobacillus pentosaceus), S3, S4, S11, S13 and S32 were the five selected strains. It is known that the length of acetic acid bacteria 16S rDNA was about 1500bp with the PCR kit, Hot Master Mix 5 PRIME (Dominique Deutcher, France).

$37^{\circ} \mathrm{C}$ was the temperature that gave the highest acid concentrations (31.5-33.9 g/l) after seven days of incubation.

Acid production up to $30 \mathrm{~g} / 1$ at $37^{\circ} \mathrm{C}$ in 7 days is very interesting for vinegar production. It's one of the highest acetic acid productions at this temperature. In fact, Amornrut and Wasu (2008) obtained $8.97 \mathrm{~g} / 1$ à $37^{\circ} \mathrm{C}$ with acetic strains isolated from fruits. An Acetobacter strain isolated by Ndoye et al. (2006) produced $25 \mathrm{~g} / 1$ in two days at $37^{\circ} \mathrm{C}$, but the medium used was enriched. It contained 4 carbon sources which may rapidly increase biomass, final acid production and diversify the acid content.

Besides, the 5 strains mentioned above can be used as acetators; indeed Ndoye et al. (2007) affirmed that strains able to produce $1.7^{\circ}$ of final acetic acid can be used in fermentations processes as acetators.

The higher productions at this temperature can be explained by a possible tolerance to temperature acquired by the strains from their natural or transferred areas (Legrand-Sow, 2004). However, Gullo and Giudici (2008) affirmed that minimum and maximum growth temperatures are difficult to define because they depend on the variability among the species and the composition of culture medium. 
(a)
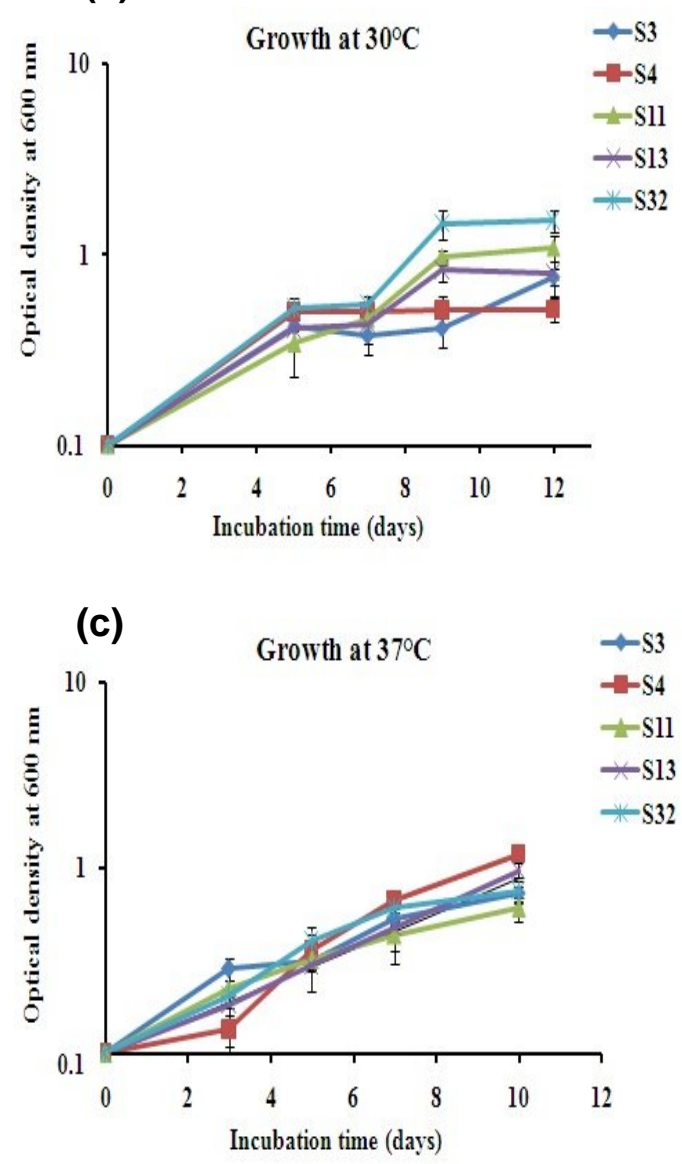

(b)

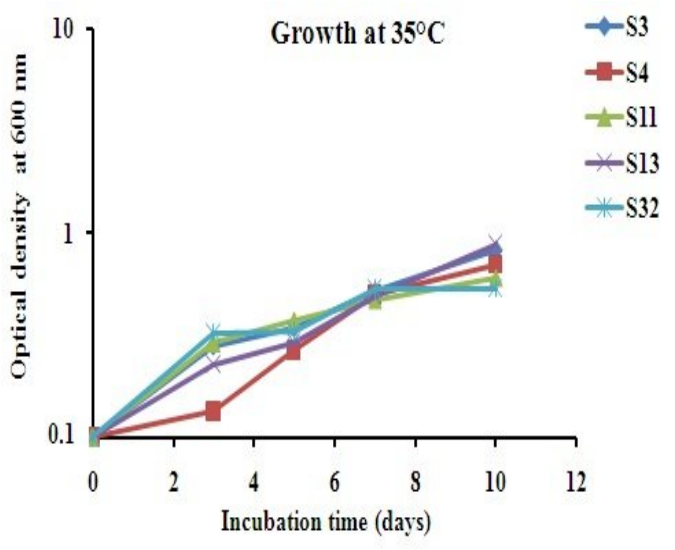

(d)

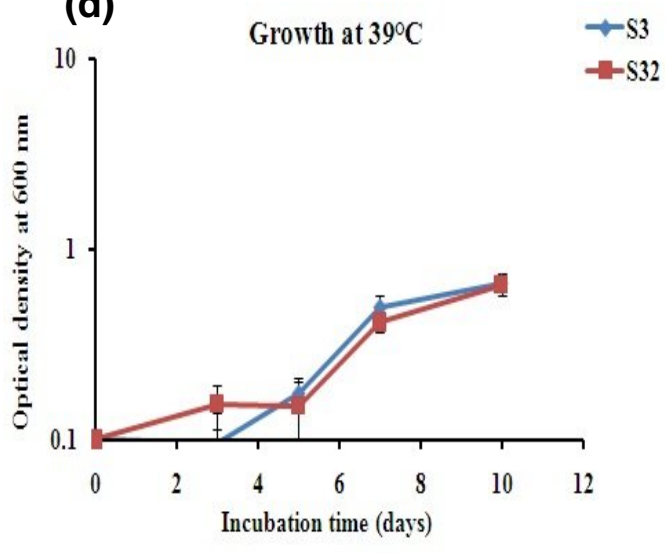

Figure 3. Growth of 5 selected A. pasteurianus strains isolated from Ivorian palm wine. Cultures were incubated at $30^{\circ} \mathrm{C}$ (a), $35^{\circ} \mathrm{C} \mathrm{(b),} 37^{\circ} \mathrm{C}$ (c) and $39^{\circ} \mathrm{C}$ (d). The HS culture medium used was supplemented with ethanol $1.5 \%$ as sole carbon source. S3: strain UFHB-LBAAB003, S4: strain UFHB-LBAAB004, S11: strain UFHB-LBAAB011, S13: strain UFHB-

LBAAB013, S32: strain UFHB-LBAAB032.

Figures $5 \mathrm{a}$ and $5 \mathrm{~b}$ showed respectively the alcohol and acid tolerance tests. Both presented two main growth phases. The first phase was a progressive decrease phase corresponding to $0-4 \%$ alcohol (Figure 5a) and 0-3\% acetic acid (Figure $5 \mathrm{~b}$ ) in the medium and the second phase was an increase one with $4-9 \%$ alcohol and 3-8\% acetic acid in the medium. A third phase (lag phase) appeared up to $9 \%$ alcohol in the medium. The values of $\Delta \log N_{10}\left(\log N_{0}-\log N_{1}\right)$ that indicate tolerance were inferior to five when alcohol and acid rates were respectively inferior to $9 \%$ and $7 \%$.

These results indicated that the strains were tolerant to $8 \%$ alcohol and $6 \%$ acetic acid according to Legrand-Sow (2004). It was also noticed that approximately $4 \%$ alcohol and 3\% acetic acid were the optimal rates for bacterial growth.

The 4\% alcohol rate for the best growth (Figure 5 a) was also observed by Kanlaya and Wasu (2009) with Gluconobacter strains isolated from honey. Some strains of Sharafi et al. (2010) were able to tolerate $7 \%$ alcohol and other strains until $11 \%$, while $78 \%$ of the strains isolated by Seyram et al. (2009) grew well with $6 \%$ alcohol and tolerated until 12\%. Du Toit and Pretorius, (2002) noticed that $\mathrm{AAB}$ cells remain viable until 10 to $14 \%(\mathrm{v} / \mathrm{v})$ of ethanol in wine but several studies performed on different $\mathrm{AAB}$ sources showed that high ethanol concentration $(10 \%-15 \%)$ could alter their amino acid requirement (Gosselé et al., 1981; Drysdale and Fleet, 1988). Generally, ethanol tolerance is a species and strain-dependent 
trait that is conditioned by temperature, $\mathrm{pH}$ and oxygen (Drysdale and Fleet, 1988; Du Toit and Pretorius, 2002). For instance, Gullo and Giudici (2006) noticed that among 25 Gluconacetobacter

(a)

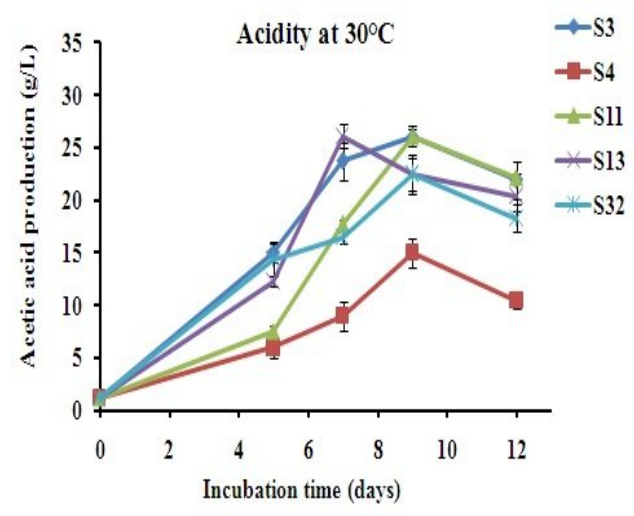

(c)

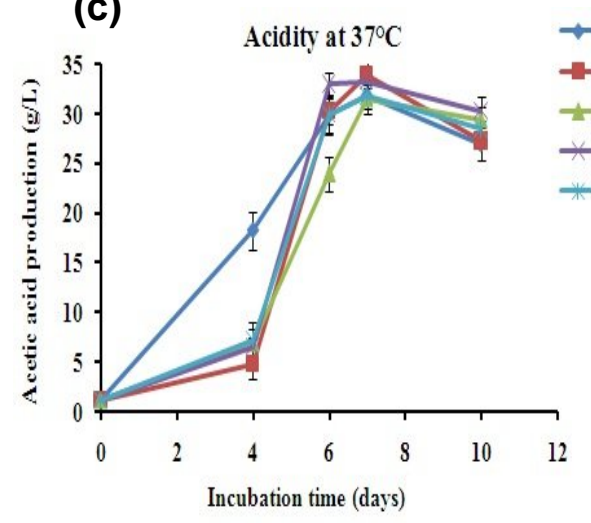

europaeus strains 11 were able to grow at 5\% ethanol while the other G. europaeus strains grew up to $10 \%$ ethanol.

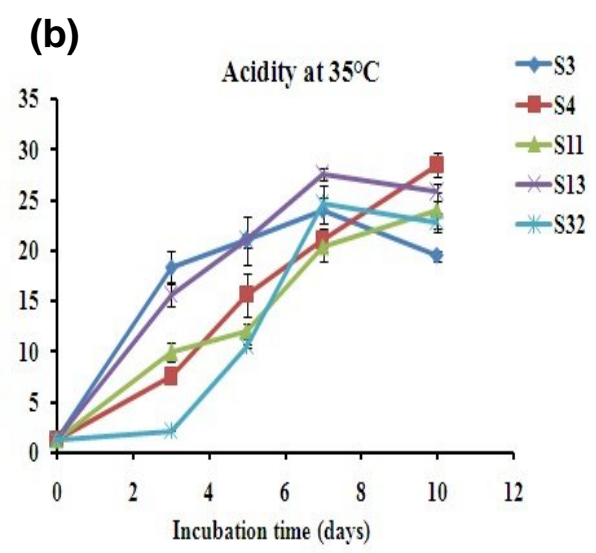

(d)

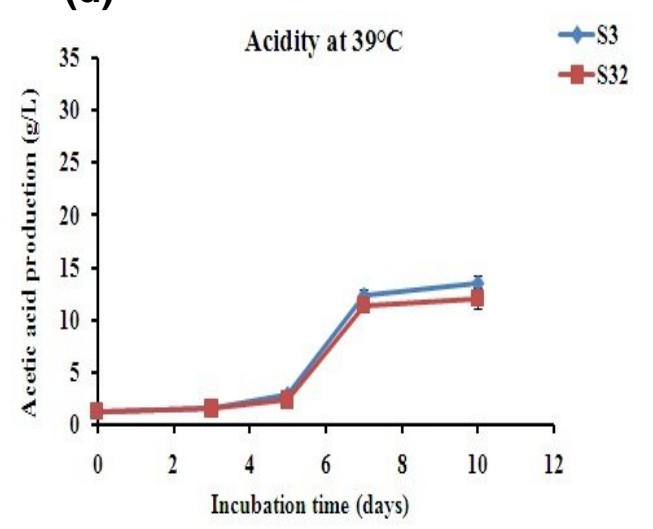

Figure 4. Acetic acid production by 5 selected A. pasteurianus strains isolated from Ivorian palm wine. Cultures were incubated at $30^{\circ} \mathrm{C}(\mathrm{a}), 35^{\circ} \mathrm{C} \mathrm{(b),} 37^{\circ} \mathrm{C}$ (c) and $39^{\circ} \mathrm{C}(\mathrm{d})$. The HS culture medium used was supplemented with ethanol $1.5 \%$ as sole carbon source. S3: strain UFHB-LBAAB003, S4: strain UFHB-LBAAB004, S11: strain UFHBLBAAB011, S13: strain UFHB-LBAAB013, S32: strain UFHB-LBAAB032.

The five selected strains were not tolerant enough to acid (Figure 5 b) comparatively to Acetobacter polyoxygenes and Acetobacter europaeus which are acidophilic strains isolated by Saeki et al. (1997). Those strains tolerated 15 to $21 \%$ acetic acid and needed 4-8\% acetic acid for optimal growth. Overwise, they have similar characteristics with some strains isolated by Sharafi et al. (2010) that gave better growth ability at $3 \%$ acid.

Concerning the influence of aeration (Figure 6 a), it was noticed that under $40 \%$ of air in flasks, acetic acid production was low (inferior to $10 \mathrm{~g} / \mathrm{l}$ ). From $40 \%$ to $60 \%$ air in flasks, it increased rapidly and achieved 16.9-18.9 g/l. Acid production continued increasing slowly until $70 \%$ air in flasks, reaching 17.9-19.7 g/l. No significant production occurred after that rate.

This high aeration rate needed by the strains to produce acid depends probably on the aerobic growth characters known in bacteria from Acetobacteriaceae family. Matsushita et al. (1994) affirmed that $\mathrm{ADH}$ and ALDH are amoung respiratory components of acetic acid bacteria, located in the cytoplasmic membrane. Furthermore, these enzymes are responsible of acetic acid production in extracellular side of bacteria (Ndoye et al., 2006). Macias et al. (1997) have also showed that an optimum dissolved oxygen concentration in the medium is necessary to obtain a maximal growth and acetification. For instance, Ndoye et al. (2006) used $80 \%$ aeration rate to obtain the highest growing characteristics of their Acetobacter strains. 
This importance of aeration would be due to oxygen. In fact, Adams (1998) affirms that oxygen is a limiting factor in acetification processes because it is only sparingly soluble in aqueous media and both temperature and solute content condition its solubility. In industrial wine vinegar produced by submerged culture in semi-continuous processes, the concentration of dissolved oxygen is the most important parameter that allows bacterial growth. However, it has been established that a high dissolved oxygen value can inhibit $\mathrm{AAB}$ growth and that the optimum concentration in semicontinuous processes is $1-3 \mathrm{mg} / \mathrm{kg}$ (RubioFernández et al., 2004).
The osmotic stress assay showed that 5\% glucose was the optimal concentration giving the highest relative growth: $10-15 \%$ glucose gave about $50 \%$ relative growth and $20 \%$ glucose was lethal for the isolates (Figure $6 \mathrm{~b}$ ). Therefore, it's better not to go above $8-9 \%$ glucose for further uses of the selected bacteria in technological processes. This agrees with previous studies made by Gullo and Giudici (2006) which indicated that even if sugars are excellent carbon sources for acetic acid bacteria, it is better not to reach high concentrations that can inhibits their growth. However, Jojima et al. (2004) showed that some extremophilic strains are able to grow up to $40 \%$ glucose.

(a)

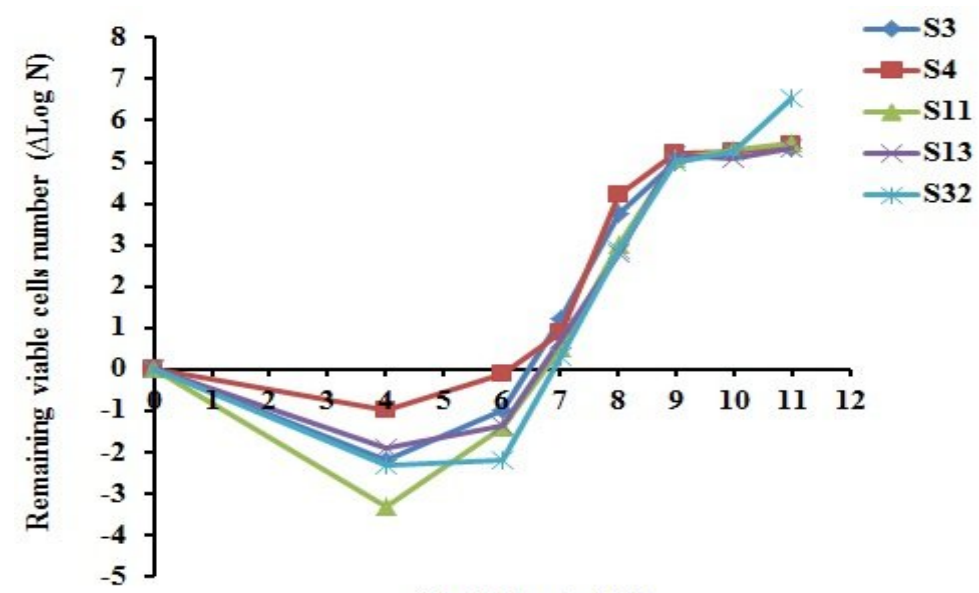

Alcohol rate (\%)

(b)

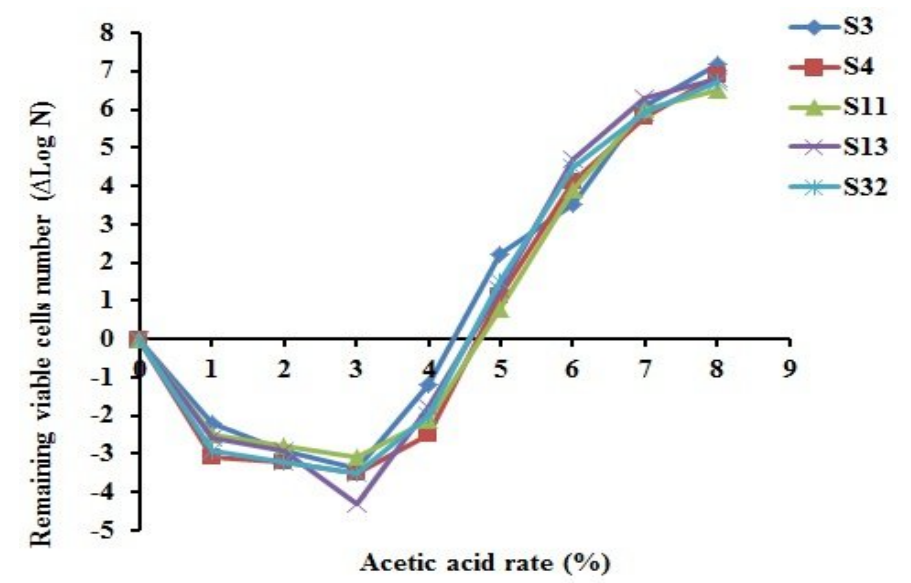

Figure 5. Tolerance to alcohol (a) and acetic acid (b) with estimation of the remaining viable biomass of 5 Acetobacter pasteurianus isolated from Ivorian palm wine. Modified HS medium was used with ethanol concentration ranging from 4 to $11 \%$ and acetic acid from 1 to $8 \%$. Cultures were incubated at $37^{\circ} \mathrm{C}$ for $48 \mathrm{~h}$ with $130 \mathrm{rpm}$ shaking. S3: strain UFHBLBAAB003, S4: strain UFHB-LBAAB004, S11: strain UFHB-LBAAB011, S13: strain UFHB-LBAAB013, S32: strain UFHB-LBAAB032. 
(a)
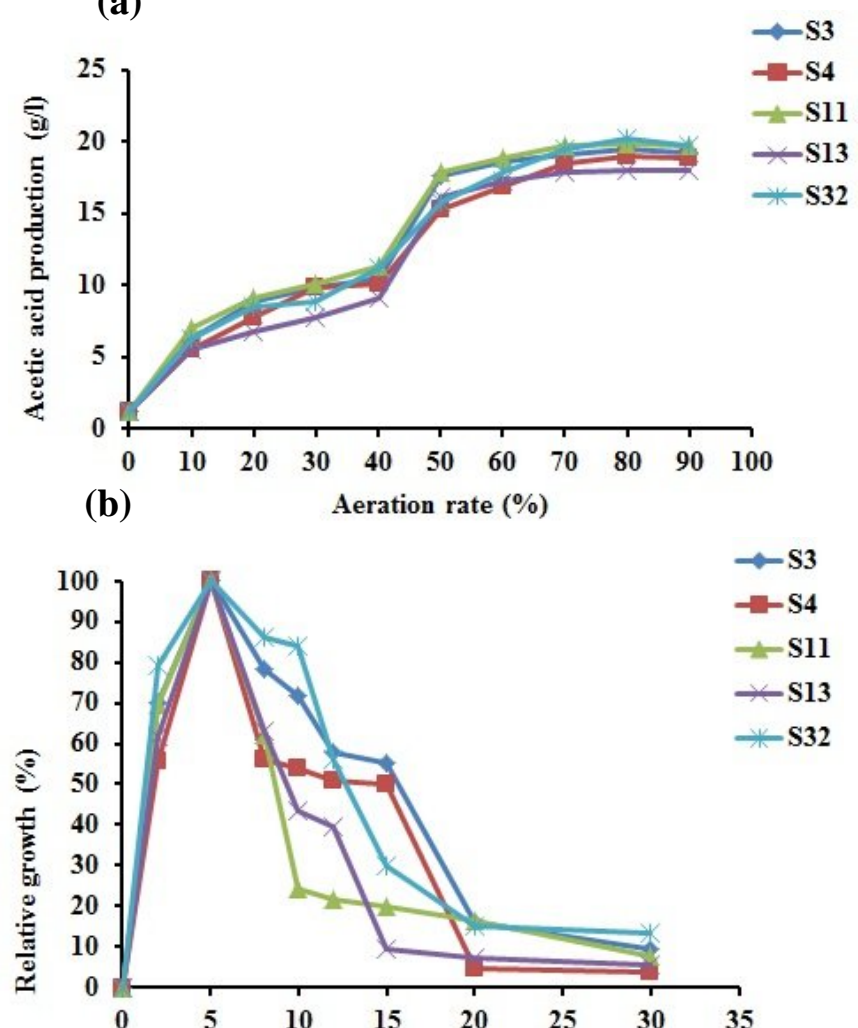

(c)

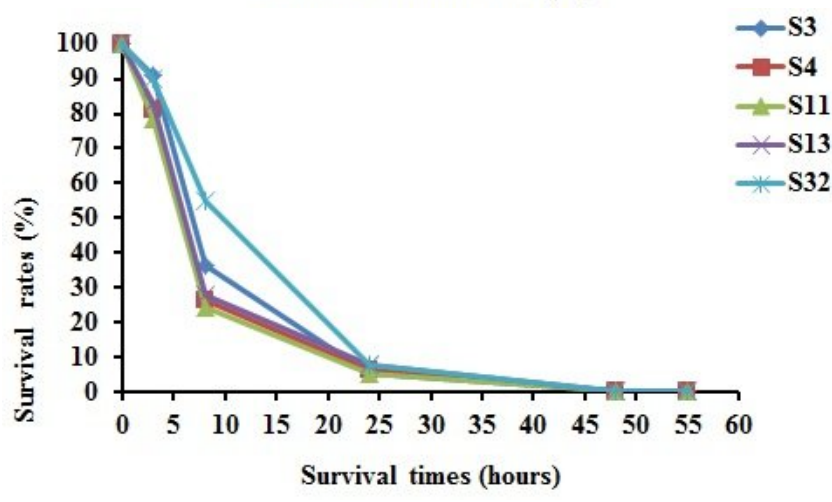

Figure 6. Physiological characterization of 5 Acetobacter pasteurianus strains isolated from Ivorian palm (Elaeis guineensis) wine. (a) Airing effect on acetic acid production. Modified HS medium was used and supplemented with 1.5 $\%$ ethanol as sole carbon source. Cultures were incubated at $37^{\circ} \mathrm{C}$ with $130 \mathrm{rpm}$ shaking for $48 \mathrm{~h}$. (b): Relative growth of strains with glucose concentrations ranging from 2 to $30 \%$ in modified HS medium. Bacterial growth was studied after 7 days at $37{ }^{\circ} \mathrm{C}$ with $130 \mathrm{rpm}$ shaking. (c): Resistance against desiccation. YGM/Mg ${ }^{2+}$ medium was used for cells growth at $30^{\circ} \mathrm{C}$ with $130 \mathrm{rpm}$ shaking during $72 \mathrm{~h}$, then cells were exposed to drying at $37^{\circ} \mathrm{C}$ during $72 \mathrm{~h}$. S3: strain UFHBLBAAB003, S4: strain UFHB-LBAAB004, S11: strain UFHB-LBAAB011, S13: strain UFHB-LBAAB013, S32: strain UFHB-LBAAB032

Resistance against desiccation of the 5 strains (Figure $6 \mathrm{c}$ ) showed that their resistance went decreasing considerably during the ten first hours. Nevertheless there still remaining more than $50 \%$ survival strains after $5 \mathrm{~h}$, more than $10 \%$ survival strains after $15 \mathrm{~h}$ and less than $0.3 \%$ after $48 \mathrm{~h}$. No survival strain was observed after $50 \mathrm{~h}$.

This result showed that the selected five $A$. pasteurianus strains were not resistant enough to desiccation. This can be due to their gram negative membranes that are naturally less resistant to desiccation than positive ones. Strain S32 is the 
only one that remains having about $30 \%$ survival rate after $15 \mathrm{~h}$ treatment. This suggests that resistance to desiccation could be strain dependant, as it was observed in other gram (-) bacteria like Campylobacter jejuni and C. coli (Fernández et al., 1985). We did not use any interference substance in this study to attenuate the temperature effect while Birgit et al. (2005) showed that bacterial resistance to desiccation is increased when using interference substance. They suggested that the higher the concentration of the interfering substance the higher was the survival rate of gram negative bacteria. However, there still remaining viable cells after $48 \mathrm{~h}$ incubation with the 5 strains even if their rates are considerably low (0.03 to $0.25 \%)$. Comparing to those of Laura et al. (2001) where among 11 Arcobacter butzleri only 2 were able to resist to desiccation at $37^{\circ} \mathrm{C}$ after $48 \mathrm{~h}$. Lewis et al. (2010) have shown that proportion of surviving cells is linked to desiccation time. They suggested that there is a correlation between microhabitat and desiccation survival, according to sampling location. Their strains isolated from a more barren and exposed location exhibit much greater desiccation resistance than those adapted to more sheltered microenvironment, with resistance beyond one week. The studied 5 strains were isolated from palm wine where growth conditions are not so hard, hence they could not be naturally as resistant. This indicates that a particular attention should be brought on the preservation of these strains as starters. Indeed, atomization and other desiccation methods like freeze-drying can be critical and must be preceded by accurate studies. Whatever, the use of starters in lyophilizated form is advantageous by avoiding risks linked to industrial manipulation with liquid inoculum. It reduces also considerably the starting time of starters activities, facilitates their carrying and their stability through the conservation time (De Vuyst, 2000).

\section{Conclusion}

In this work, 104 strains were isolated from Ivorian palm wine. After thorough screening, five strains presenting the best potentialities were characterized. Morphological, biochemical, physiological and molecular examination indicated that all isolates were all Acetobacter pasteurianus strains and that they can be successfully used for high vinegar production. They showed acceptable acid and alcohol tolerance. Their acetic acid production above $30 \mathrm{~g} / \mathrm{l}$ is one of the best rates obtained by acetic bacteria and their thermotolerant properties at $37^{\circ} \mathrm{C}$ are useful in sub-African countries where temperature is generally above $30^{\circ} \mathrm{C}$. Nethertheless, accurate studies must be performed on these strains according to their preservation as starters for industrial vinegar production.

\section{References}

Adachi, O., D. Moonmangmee, H. Toyama, M. Yamada, E. Shinagawa and K. Matsushita. 2003. New developments in oxidative fermentation. Appl. Microbiol. Biotechnol. 60:643-653.

Adams, M.R. 1998. Vinegar. Microbiology of fermented foods. In: J. B. Woods (Eds.), pp. 1-44. Blacki Academic and Professional, London.

Amornrut, M. and P. A. Wasu. 2008. Isolation of thermotolerant acetic acid bacteria from fruits for vinegar production. Res. J. Microbiol. 3:209-212.

Andelib, A. Y. and D. A. Nuran. 2009. Isolation of cellulose producing bacteria from wastes of vinegar fermentation. In: Proceedings of the World Congress on Engineering and Computer Science Vol I, San Francisco, USA. pp. 978-988.

Beheshti, M. K. and R. Shafiee. 2009. Isolation and identification of an Acetobacter strain from iranian white-red cherry with high acetic acid productivity as a potential strain for cherry vinegar production in food and agriculture biotechnology. World Acad. Sci. Eng. Technol. 30:173-176.

Birgit, H., A. Andrea and B. Reinhard. 2005. Effects of the drying conditions on different gram negative bacteria on stainless steel discs used in the "quantitative surface test for the evaluation of bactericidal activity of chemical disinfectants" (EN 14349) (2005). ISAH Warsaw, Poland. 2:217-220.

Brosius, J., L. M. Palmer, P. J. Kennedy and H. F. Noller. 1978. Complete nucleotide sequence of a 16S ribosomal RNA gene from Escherichia coli. Proc. Natl. Acad. Sci. USA. 75:4801-4805.

Chinnawirotpisan, P., G. Theeragool, S. Limtong, H. Toyama, O. Adachi and K. Matsushita. 2003. Quinoprotein alcohol dehydrogenase is involved in catabolic acetate production, while NAD-dependent alcohol dehydrogenase in ethanol assimilation in Acetobacter pasteurianus SKU1108. J. Biosci. Bioeng. 
96:564-571.

De Ley, J., M. Gillis and J. Swings. 1984. Acetobacteriaceae. In: N. R. Krieg and J. G. Holt (Eds.), pp. 267-278. Bergey's Manual of Systematic Bacteriology. Williams and Wilkins, Baltimore, USA.

De Vuyst, L. 2000. Technology aspects related to the application of functional starter cultures. Food Technol. Biotechnol. 38:105-112.

Drysdale, G. S. and G. H. Fleet. 1988. Acetic acid bacteria in winemaking:a review. Am. J. Enol. Vitic. 39:143-154.

$\mathrm{Du}$ Toit, W. J. and I. S. Pretorius. 2002. The occurrence, control and esoteric effect of acetic acid bacteria in winemaking. Ann. Microbiol. 52:155-179.

Duthathai, F. and P. A. Wasu. 2007. Application of chemical dyes as colour indicator for selective isolation of acetic acid bacteria. Res. J. Microbiol. 2:855-888.

Fernández, H., M. Vergara and F. Tapia. 1985. Desiccation resistance in thermotolerant Campylobacter species. Infect. 13:197-200.

Gosselé, F., M. M. Den, V. L. Van, J. Swings and J. De Ley. 1981. The nitrogen requirements of Gluconobacter, Acetobacter and Frateuria. Antonie van Leeuwenhoek. 47:289-296.

Gullo, M. and P. Giudici. 2006. Isolation and selection of acetic acid bacteria strains for traditional balsamic vinegar. Industrie Delle Bevande. 35:345-350.

Gullo, M. and P. Giudici. 2008. Acetic acid bacteria in traditional balsamic vinegar: Phenotypic traits relevant for starter cultures selection. Int. J. Food Microbiol. 125:46-53.

Holt, J. G., N. R. Krieg, P. H. A. Sneath, J. T. Stanley and S. T. Williams. 1994. Bergey's Manual of Determinative Bacteriology. $9^{\text {th }}$ Eds. pp. 164-181. Williams and Wilkins, Baltimore, USA.

Illeghems, K., L. De Vuyst and S. Weckx. 2013. Complete genome sequence and comparative analysis of Acetobacter pasteurianus 386B, a strain well-adapted to the cocoa bean fermentation ecosystem. BMC Gen. 526:14712164.

Kanlaya, K. and P. A. Wasu. 2009. Isolation of acetic acid bacteria from honey. Maejo Int. J. Sci. Technol. 3:71-76.
Laura, O., W. Myra, F. Heriberto. 2001. Desiccation resistance in Arcobacter Butzleri. Braz. J. Microbiol. 32:311-312.

Legrand-Sow, N. 2004. Sélection et caractérisation de bactéries lactiques d'origine africaine en vue d'une utilisation comme probiotiques. $\mathrm{Ph}$. D. dissertation. Faculté universitaire des sciences agronomiques de Gembloux. Belgium.

Lewis, D. R., F. R. David, W. J. Samantha and W. M. John. 2010. Desiccation resistance of Antarctic Dry Valley bacteria isolated from contrasting locations. Antarct. Sci. 22:171172.

Lisdiyanti, P., H. Kawazaki, Y. Widyastuti, S. Saono, T. Seki, Y. Yamada, T. Ushimura and K. Komagata. 2002. Kozakia baliensis gen. nov., sp. nov., a novel acetic acid bacterium in the $\alpha$-Proteabacteria. Int. J. Syst. Evol. Microbiol. 52:813-818.

Lu, S. F., C. Fwu-Ling and Han-Ken. 2000. Thermotolerant and high acetic acidproducing Acetobacter bacterium. US Patent 6096528.

Macias, M., I. Caro and D. Cantero. 1997. Optimum operating conditions in closedsystem industrial acetifiers (semi-continuous operation): A study by computer simulation. Chem. Eng. J. 65:201-207

Matsushita, K., H. Toyama and O. Adachi. 1994. Respiratory chains and bioenergetics of acetic acid bacteria. Adv. Microb. Physiol. 36:247301.

Ndoye, B., S. Lebecque, R. Dubois-Dauphin, L. Tounkara, T.A. Guiro, C. Kere, B. Diawara and P. Thonart. 2006. Thermoresistant properties of acetic acid bacteria isolated from tropical products of Sub-Saharan Africa and destined to industrial vinegar. Enzyme Microb. Technol. 39:916-923.

Ndoye, B., F. Weekers, B. Diawara, T. A. Guiro and P. Thonart. 2007. Survival and preservation after freeze-drying process of thermotolerant acetic acid bacteria isolated from tropical products of Subsaharan Africa. J. Food. Eng.79:1374-1382.

Okafor, N. 1975. Microbiology of nigerian palm wine with particular reference to bacteria. J. Appl. Bacteriol. 38:81-88.

Ould El Hadj, M. D., A. H. Sebihi et O. Siboukeur. 
2001. Qualité hygiénique et caractéristiques physico-chimiques du vinaigre traditionnel de quelques variétés de dattes de la cuvette de Ouargla. Rev. Energ. Ren.: Production et Valorisation-Biomasse. p. 87-92.

Rubio-Fernandez, H., M. D. Salvador and G. Fregapane. 2004. Influence of fermentation oxygen partial pressure on semi-continuous acetification for winevinegar production. Eur. Food Res. Technol. 219:393-397.

Saeki, A, K. Matsushita, S. Takeno, M. Taniguchi, H. Toyama, G. Theeragool, N. Lotong and Adachi O. 1999. Enzymes responsible for acetate oxidation by acetic acid bacteria. Biosci. Biotechnol. Biochem. 63:2102-2109.

Saeki, A., M. Taniguchi, K. Matsushita, H. Toyama, G. Theeragool, N. Lotong and O. Adachi. 1997. Microbiological aspects of acetate oxidation by acetic acid bacteria, unfavorable phenomena in vinegar fermentation. Biosci. Biotechnol. Biochem. 61:317-323.

Seyram, S. K., A. Yaovi, K. D. Simplice and D. S. Comlan. 2009. Study of pineapple peelings processing into vinegar by biotechnologies. Pakistan J. Biol. Sci. 12:859-865.
Sharafi, S. M., I. Rasooli and K. Beheshti-Maal. 2010. Isolation, characterization and optimization of indigenous acetic acid bacteria and evaluation of their preservation method. Iran J. Microbiol. 2:41-48.

Urakami, T., J. Tamaoka, K. Suzuki and K. Komagata. 1989. Acidomonas gen. nov., incorporating Acetobacter methanolicus as Acidomonas methanolica comb. Nov. Int. J. Syst. Evol. Bacteriol. 39:50-59.

Webley, D. M. 1953. A simple method for producing microcultures in hanging drops with special reference to organisms utilizing oils. J. Gen. Microbiol. 8:66-71.

Yamada, Y., R. Hosono, P. Lisdyanti, Y. Widyastuti, S. Saono, T. Uchimura and K. Komagata. 1999. Identification of acetic acid bacteria isolated from Indonesian sources, especially of isolates classified in the genus Gluconobacter. J. Gen. Appl. Microbiol. 45:23-28.

Jojima, Y., Y. Mihara, S. Suzuki, K. Yokozeki, S. Yamanaka and R. Fudou. 2004. Saccharibacter floricola gen. nov., sp. nov., a novel osmophilic acetic acid bacterium isolated from pollen. Int J. Syst. Evol. Microbiol. 54:2263-2267. 